\title{
An Investigation of the Perceived Life Satisfaction and Social Support Levels of the Vocational High School for Hearing-Impaired Students According to Active Participation in Sports Activities
}

\author{
Mustafa Barıș Somoğlu (Corresponding author) \\ Ministry of National Education, Physical Education and Sports Teacher, Artvin, Turkey \\ Tel: 90-554-320-80-02Ｅ-mail: barissomoglu@gmail.com
}

Hamit Cihan

Coaching Education Department, Trabzon University, Trabzon, Turkey

Tel: 90-533-639-12-11Ｅ-mail: hamitcb@trabzon.edu.tr

Received: November 5, $2021 \quad$ Accepted: November 27, 2021

Published: December 31, 2021

doi:10.5296/jei.v7i3.19270 URL: https://doi.org/10.5296/jei.v7i3.19270

\begin{abstract}
The aim of this article was to examine the perceived life satisfaction and social support levels of the vocational high school students according to active participation in sports activities with respect to some variables, and determine the relation between certain variables and involvement in sports. The study group of the research consisted of 554 students studying at various vocational high schools for hearing impaired during the 2014-2015 education year. The sample was composed of 327 male $(60.1 \%$ of the sample) and 217 female $(39.9 \%$ of the sample) students. "Personal Information Form", "Multidimensional Scale of Perceived Social Support (MSPSS)" developed by G. D. Zimet, Dahlem, S. G. Zimet, and Farley (1988) and adapted to Turkish by Eker, Akar, and Yaldiz (2001), and "The Satisfaction With Life Scale (SWLS)" developed by Diener, Emmons, Larsen, and Griffin (1985) and adapted to Turkish by Köker (1993), were used for data collection. The statistical methods and tools used for data evaluation were descriptive statistics, T-Tests for independent groups, one-way analysis of variance (one-way ANOVA), multi-way analysis of variance (multi-way ANOVA) and Tukey's multiple comparison test. In order to determine the relationship between dependent
\end{abstract}


variables, Pearson Correlation Test and Regression Test were administered. Based on the findings of study, the study group members tended to have over moderate social support and life satisfaction levels and there was a moderately positive correlation between the social support and life satisfaction levels. The perceived social support and life satisfaction levels of the students demonstrated significant differences in respect to the sportsmanship status, sport branches, active years of sports involvement. The study revealed that participation in sports activities play an important role on the perceived social support and life satisfaction levels of the vocational high school for the hearing-impaired students.

Keywords: Physical education and sports, Hearing-impaired, Social support, Life satisfaction

\section{Introduction}

Education has been continuing among adults, children and youth since the existence of man (Kincal, 2004). Education, which is a field as old as the history of humanity, is generally defined as the process of changing behavior in the individual. What is expected from education, which starts in the family and continues on the street, at school, at the workplace, is to reveal the hidden powers and talents of individuals and help them develop at the highest level (Varış, 1991). Wherever human beings exist, there are individual differences. Each individual's physical structure, strengths and weaknesses, limitations, competencies, interests and abilities, emotional characteristics, learning characteristics and speed are different from each other. Contemporary education in the developing world is planned by taking into account individual differences in order to provide services in line with the needs of individuals. However, the general education system has been organized to meet the needs of individuals with ordinary or average competence and capacity within certain limits (Doğru, 2004). In every society, besides healthy individuals with normal development, there are also individuals with special needs, in other words those who need special education, who differ significantly from their peers in terms of their individual and developmental characteristics. According to Kargin (2004), individuals with special needs are individuals who have different needs from their peers in terms of their physical, mental, emotional and social characteristics.

One of the most effective ways of bringing disabled people into social life is to ensure that they receive an education like normal individuals. However, the education of the hearing impaired differs from the education of normal individuals, so they need private schools, classrooms and teachers (Prime Ministry Administration for the Disabled, 2009). It is thought that disabled children are unhappy due to the negativities and difficulties they experience from time to time. Keeping their sense of hope alive; it will be possible by providing the help and support they need (Etci, 2013). However, knowing the factors that affect their life satisfaction positively or negatively is important in terms of planning healthy aids and supports.

Physical education and sports constitute the most important step in reaching the goals of general education (Çöndü, 2004). Sport fulfills an extremely important function for the harmonization targeted in special education, by enabling disabled individuals to come together with healthy individuals and disabled individuals. Thus, thanks to sports, disabled 
individuals and healthy individuals meet at a common point, develop positive attitudes and behaviors, minimize feelings of loneliness, expand their social circles and lead a more quality life (Özer, 2010).

On the other hand, the introduction of sports for the disabled started with the purpose of curing their mental health and physical deficiencies and progressed to close the social gap between them and the society (Sevindi, 2002). Regardless of which disability group they belong to, sports are of great importance for people with disabilities. First of all, sports increase the self-confidence of people with disabilities. It greatly contributes to their rehabilitation. Today, there is hardly a rehabilitation program in our country and in the West that does not involve sports. In addition, sports enable people with disabilities to integrate into society. Disabled people who make their names known by doing sports achieve many successes by representing their country in international competitions. Sport is extremely valuable for both physically and mentally disabled people and is an important tool in meeting the needs of individuals with disabilities to enjoy movement, have fun and achieve success (Brouwer \& Ludeke, 1995). Sports teaches people to cope with and alleviate their disability, gives pleasure, provides communication and sharing, increases life motivation, and provides positive personality traits such as honesty, tolerance and cooperation (Özer, 2010). The place of sports in the life of the disabled is undeniable. Through sports, the relationships of the disabled with the people around them, their feelings of sharing and self-sacrifice improve and their self-confidence increases. It is possible for disabled people to cooperate, communicate and share among themselves and with non-disabled people, play games together and participate in social activities together (Özdinç, 2005).

The concept of social support was first examined in studies conducted in the field of preventive health in the 1960s, its relationship with health was investigated, and it was determined that social support had positive effects on health in stress and stress-related diseases (Sorias, 1988a, 1988b). Social support has been defined as "the physical and psychological assistance provided by family, friends, neighbors or institutions to an individual in a difficult situation" (Leavy, 1983). "Social support is the help an individual receives from his/her environment. This help gives the individual the perception that he is valuable and acts as a buffer in the individual's struggle with stress" (Kay, 2002). It is thought that social supports directly and positively affect physical and mental health by meeting basic social needs such as love, compassion, self-esteem and belonging to a group. In addition, social support is the most important helper of the person in coping with life difficulties (Sorias, 1988a).

Perceived social support from parents and friends during adolescence plays an important role in increasing life satisfaction. It is also important for university student (Kırkbir \& Zengin, 2020). Diener and Fujita (1995) emphasize that social resources such as family support, close friendships and personal resources that an individual uses in establishing social relationships are important in subjective well-being, and they state that life satisfaction will be high if the individual's personal goals are compatible with his personal resources and social resources. Individuals can receive social support from their spouse, family and friends, as well as from leisure activities, entertainment activities, community programs, and professional people and 
institutions (Siklos \& Kerns, 2006). According to Diener, the main purpose of services in the fields of education, health and environment in societies should be to increase subjective well-being and the effect of different social policies on subjective well-being should be closely monitored (Diener \& Seligman, 2004). There are various factors that affect life satisfaction. Many studies have shown that social support affects individuals' life satisfaction (Armsden \& Greenberg, 1987; Barrera, Chassin, \& Rogosch, 1993; Canetti, Bachar, Galili-Weisstub, De-Nour, \& Shalev 1997; Ducharme, Doyle, \& Markiewicz, 2002; Golbeck, Schmitz, Besier, Herschbach, \& Henrich, 2007; Lan-Liu, 2006; Perrone, Webb, \& Jackson, 2007; Yarcheski, Mahon, \& Thomas, 2001). In the literature review on the subject, social support (Cheng, 1997; Çakır, 1993; Çakır \& Palabıyıkoğlu, 1997; Çeçen, 2008; Demaray \& Malecki, 2002; Erelçin, 1988; Gençdoğan, 2003; Güngör, 1994; Kılıç, Özbay, Gökay, Aktaş, \& Şirvanl1-Özen, 1998; Şencan, 2009; Ustabaş, 2011; Mason, 2004; Nicpon, 2007; Rigby, 2000; Rueger, 2010; Okanlı, 1999; Savi-Çakar \& Karataş, 2012; Soylu, 2002; Ünlü, 2001; Yalçın, 2004; Yıldırım, 2000; Zaimoğlu, 1991) and life satisfaction concepts (Akkan, 2010; Chow, 2005; Çeçen, 2007; Dikmen, 1995; Deniz \& Y1lmaz, 2004; Gilman, 2001; Gürbüz, 2008; Hilooğlu, 2009; Kaya, 2006; Köker, 1991; Kırc1, Çelik, \& Korkmaz, 2014; Korkut, 2012; Myers \& Diener, 1995; Taş, 2011; Ünlü \& Şahin, 2013; Vinson \& Ericson, 2012; Young \& Miller, 1995; Kirkbir \& Zengin, 2020) have studied the concepts separately, but a limited number of studies were found that investigated the two concepts together (Guerette, 2011; Fife, Adegoke, Mccoy, \& Brewer, 2011; Masako, 1987; Kafetsios, 2006; Önalgil, 2012; Yalçın, 2015). In addition, it is thought that the study is important in terms of examining the perceived social support level and life satisfaction of the hearing-impaired students in high schools in Turkey according to their athletic status, and revealing the relationship between the variables to be determined. In addition, answers to the following questions will be sought.

Research Questions:

(1) Is there any meaningful relationship between life satisfaction and perceived social support levels of the vocational high school for hearing-impaired students according to active participation in sports activities?

(2) Is there any meaningful difference life satisfaction and perceived social support of the vocational high school for hearing-impaired students according to sport ststues, sport branch and years of sports?

(3) Does perceived social support of hearing disabled students, who are doing sports, estimate life satisfaction?

\section{Method}

\subsection{Research Model}

The research was carried out with the screening method within the framework of the quantitative approach. In this method, of which purpose is to describe the past or present situation as it exists (Kuzu, 2013), the important thing in this method is to define the event, individual or object that is the subject of the research as it is in its own conditions and to observe it without trying to change the current situation (Karasar, 2012). Quantitative 


\section{Macrothink

research is a type of research that puts facts and events in an observable, measurable and quantifiable way by objectifying them. The research in which observations and measurements are repeated and objective is called quantitative research (Yıldırım \& Şimşek, 2005).

The study consisted of two stages. In the first stage of the study, the literature on social support and life satisfaction was reviewed and the available studies were examined and a theoretical framework was prepared. In the second stage of the study, the most appropriate one of the previously used scales related to the subject was determined and data were collected from the hearing-impaired students.

\subsection{Study Groups}

The study group of the research consisted of a total of 327 (60.1\%) males and $217(39.9 \%)$ females studying at hearing impaired vocational high schools affiliated to the Special Education Directorate under the Ministry of National Education in the 2014-2015 academic year. It consists of 544 hearing impaired students. 49 (9\%) students from Trabzon Çamlık Special Education Vocational High School, 64 (11.76\%) students from Elazı̆ Special Education Vocational High School, 40 (7.35\%) students from Samsun Special Education Vocational High School, 160 (29.41\%) students, 186 (34.19\%) students from Büyükçekmece Special Education Vocational High School and 45 (8.27\%) students from Ordu Nuriye Halit Çebi Special Education Vocational High School constitute the research group.

While determining the research group, "Convenience Sampling" method was used. In cases where this technique is used, the sample consists of participants that the researcher can easily reach. Low cost in application, ease of obtaining permission, easy time sampling is made due to the facts such as earning and labor shortage (Şimşek, 2012). In survey studies, 350-500 samples are usually sufficient for a large group of 5000 or more (Dillman \& Salant, 1994). Accordingly, the participant group of the research $(n=544)$ is quite sufficient for the population of the research. Demographic information of the students is presented in the table below. 


\section{Macrothink}

Table 1. Demographic information distribution of participants

\begin{tabular}{|c|c|c|c|}
\hline \multicolumn{2}{|l|}{ Variables } & $\mathrm{n}$ & $\%$ \\
\hline \multirow{3}{*}{ Status of Sportsmanship } & Yes & 155 & 28.5 \\
\hline & No & 389 & 71.5 \\
\hline & Total & 544 & 100 \\
\hline \multirow{3}{*}{ Gender } & Female & 217 & 39.9 \\
\hline & Male & 327 & 60.1 \\
\hline & Total & 544 & 100 \\
\hline \multirow{4}{*}{ Age } & $14-16$ & 179 & 32.9 \\
\hline & $17-19$ & 317 & 58.3 \\
\hline & $20-22$ & 48 & 8.8 \\
\hline & Total & 544 & 100 \\
\hline \multirow{3}{*}{ Sports Branch } & Team Sport & 112 & 20.6 \\
\hline & Individual Sport & 43 & 7.9 \\
\hline & Total & 155 & 28.5 \\
\hline \multirow{3}{*}{ Year of Sport } & Between 1-5 years & 97 & 17.8 \\
\hline & Between 6-10 years & 58 & 10.7 \\
\hline & Total & 155 & 28.5 \\
\hline
\end{tabular}

\subsection{Data Collection Tools}

A data collection tool consisting of two parts was applied to the candidates in order to examine the perceived social support level and life satisfaction of the hearing-impaired high school students according to their athletic status. The first part of the data collection tool is in the form of a personal information form, which aims to determine the demographic characteristics of the candidates. In the second part, there are scales consisting of expressions for the measurement of perceived social support level and life satisfaction. Detailed information about data collection tools is given below.

\subsubsection{Multidimensional Perceived Social Support Scale (MSPSS)}

"Multidimensional Perceived Social Support Scale", developed by Zimet et al. (1988) and adapted into Turkish by Eker, Arkar, and Yaldiz (2001), was used to determine the perceived social support levels of hearing-impaired students. The scale is a 7-point Likert scale (1 definitely no, 7 definitely yes) and consists of 12 items. There is no reverse item in the scale. The scale has three subgroups reflecting the sources of support, namely family, friend and 
personal support, and each group consists of 4 items. 3.4.8.11 items on the scale measure family support, 6.7.9.12 items measure friend support, and 1.2.5.10 items measure support from a special person. The lowest score that can be obtained from the subscales is 4 , and the highest score is 28 . The lowest score that can be obtained from the total scale score by adding the scores from the subscales is 12 , and the highest score is 84 . A high score from the scale indicates high perceived social support. In the reliability analyzes of the scale, the internal consistency Cronbach $\alpha$ reliability coefficient was found to be 0.77-0.92 (Eker \& Arkar, 1995). The Cronbach $\alpha$ coefficient was found to be $0.80-0.95$ in the factor structure, validity and reliability of the revised form of the Multidimensional Scale of Perceived Social Support by Eker et al. (2001). In this study, the Cronbach $\alpha$ coefficients for the internal consistency of the scale; .92 for total multidimensional perceived social support, .85 for family support, .77 for friend support, and .84 for private person support.

\subsubsection{The Satisfaction with Life Scale (SWLS)}

The Satisfaction with Life Scale (SWLS), developed by Diener, Emmons, Larsen, and Griffin (1985), was used to determine the level of life satisfaction of hearing-impaired students. In factor analysis, it explains $66 \%$ of the total variance with a single factor. The internal consistency of the scale was found to be .87 . In the adaptation study consisting of a total of 5 items, which was brought into Turkish by Köker (1991), it was found that the scale showed a correlation of .85 in test-retest reliability. As proof of the validity of the scale, the item-total correlation was examined and correlation coefficients of .73 for item 1, .71 for item 2, .76 for item 3,.75 for item 4, and .80 for item 5 were found (Köker, 1991). In this study, the Cronbach $\alpha$ coefficient for the internal consistency of the scale was found to be .86 .

\subsection{Research Design}

The "Multidimensional Scale of Perceived Social Support" and "Scale of Life Satisfaction" used in the research were applied to the hearing-impaired students studying at Special Education Hearing Impaired Vocational High Schools in the provinces of Trabzon, Bursa, Istanbul, Elazig, Samsun and Ordu in the 2014-2015 academic year. Prior to the implementation of the data collection tools, permissions were obtained from the schools through Karadeniz Technical University, Institute of Educational Sciences. Questionnaire forms were reproduced by taking into account the number of students studying in schools where permission was obtained for the application. In the application part, with the guidance and help of teachers who know sign language, with the knowledge of the school principal, the rules to be followed during the application were explained in detail and the students were provided to fill in the questionnaires. Recycling was provided by the guidance teachers at the designated schools. Since some of the applied and returned questionnaires were excluded from the study due to incomplete filling, continuous coding at the same level, and similar reasons, 544 questionnaires were included in the study with their final version out of a total of 645 questionnaires sent. Then, the valid and acceptable questionnaires applied to the hearing-impaired students were coded to be evaluated in the SPSS package program, transferred to the computer environment, necessary analyzes were made and the process was followed. 


\subsection{Data Analysis}

Statistical analyzes made within the scope of the research were carried out through the SPSS 20th statistical package program. As a statistical method in the evaluation of data; descriptive statistics (frequency, arithmetic mean, standard deviation); T-Test, one-way analysis of variance (ANOVA), multivariate ANOVA (MANOVA), Tukey multiple comparison, Pearson Correlation and Regression tests were used for independent groups.

Whether the data meet the prerequisites of parametric tests is decided by examining the Skewness and Kurtosis (normal distribution of the data) values and the Levene (equality of variances) test results (Büyüköztürk, 2013). In order to test whether the data obtained in this study provide a normal distribution, skewness and kurtosis values were determined by descriptive statistics. Since the skewness and kurtosis are within an acceptable range, that is, at the level of \pm 2 , it can be said that the data are normally distributed (Kjøbli \& Ogden, 2009). A skewness value greater than 3 is considered "extremely skewed", and a kurtosis value greater than 10 is considered "extremely flattened" (Kline, 2011).

\section{Results}

In this section, the statistical analysis of the social support and life satisfaction perceived by hearing impaired students who do sports or not are given. Descriptive statistics of the properties specified in accordance with the first sub-objectives identified in this study, are given to the findings of the independent variables of personal information obtained from participants. Moreover, findings and analysis that are based on the relationship between perceived social support and life satisfaction students with hearing impairment, doing sport and not have been given.

\subsection{Related Results with Multidimensional Perceived Social Support}

In Table 2, the arithmetic mean, standard deviation, the minimum and maximum values for the skewness and kurtosis values related to the points taken from factors which constitutes multidimensional perceived social support scale (MSPSS) are given according to the ones who do sports and the others who don't. In Table 2 that shows the research in which students who are subject to in terms of MSPSS sport; the arithmetic mean and the standard deviation of the ones doing sports are $5.07 \pm 1.33$, whereas arithmetic mean and standard deviation of those who are not doing sports are $3.95 \pm 1.40$. Moreover, the distortions on whether they satisfy the assumptions of normality of students MSPSS total score obtained from the dimensions and kurtosis are calculated. Distortions in MSPSS spore size, as seen in Table 2, the values for these coefficients $-.348,-.778$ kurtosis: skewness of those dimensions doing sports $.249,-.516$ kurtosis is calculated as. The data obtained from MSPSS are seen on the normal distribution assumption. Sports Special People who support the dimensions of the MSPSS significant other (SO) of the arithmetic mean and standard deviation of scores obtained from size 4.93 \pm 1.55 ; Family Support (FAM), the arithmetic mean and standard deviation of the scores obtained from the size of $5.30 \pm 1.45$ and Friends Support (FRI) the arithmetic mean and standard deviation of scores obtained from size is $4.97 \pm 1.40$. In addition, sports that skew on whether they satisfy the assumptions of normality of the total score 
obtained from students MSPSS the lower size and kurtosis are calculated. SO distortions in size as shown in Table 2 values for these coefficients -.351, -.915 kurtosis; FAM distortions in size $-.429,-.757$ kurtosis and skewness in the FRI size $-.425,-.349$ is calculated as kurtosis. Sports students who took the size of the data obtained from MSPSS seen that the normal distribution assumption. Significant other support to the dimensions of the MSPSS students (SO) of the arithmetic mean and standard deviation of the scores obtained from the size and $3.56 \pm 1.64$; family support (FAM), the arithmetic mean and standard deviation of scores obtained from size were $4.24 \pm 1.60$ and friends support (FRI) the arithmetic mean and standard deviation of scores obtained from size is 4:04 $\pm 1: 46$. Significant other support to the dimensions of the MSPSS students (SO) of the arithmetic mean and standard deviation of the scores obtained from the size and 3.56 \pm 1.64 ; family support (FAM), the arithmetic mean and standard deviation of scores obtained from size were $4.24 \pm 1.60$ and Friends Support (FRI)

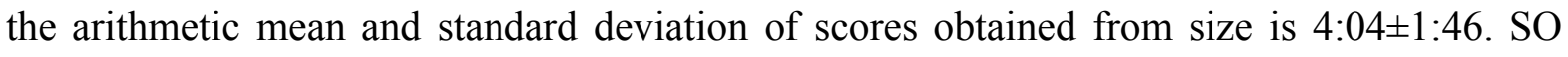
distortions in size as shown in Table 2 values for these coefficients of .514, -.805 kurtosis; FAM size distortions of .109, -.700 kurtosis and skewness in the FRI size -.014, -.504 is calculated as kurtosis.

Table 2. Descriptive statistics related multidimensional perceived social support scores

\begin{tabular}{|l|l|l|l|l|l|l|l|l|}
\hline Doing Sport & Article number & $\mathrm{n}$ & $\overline{\mathrm{x}}$ & Ss & Skewness & Kortosis & Min. & Mak. \\
\hline SO & 4 & 155 & 4.93 & 1.55 &,- 351 & $-0,915$ & 4 & 28 \\
\hline FAM & 4 & 155 & 5.30 & 1.45 & -.429 & -0.757 & 4 & 28 \\
\hline FRİ & 4 & 155 & 4.98 & 1.40 & -.425 & -0.349 & 4 & 28 \\
\hline MSPSS & 12 & 155 & 5.07 & 1.33 & -.348 & -.778 & 12 & 84 \\
\hline Not Doing Sport & Article number & $\mathrm{n}$ & $\overline{\mathrm{x}}$ & Ss & Skewness & Kortosis & Min. & Mak. \\
\hline SO & 4 & 389 & 3.56 & 1.64 & 0.514 & -0.805 & 4 & 28 \\
\hline FAM & 4 & 389 & 4.24 & 1.60 & 0.109 & -0.700 & 4 & 28 \\
\hline FRI & 4 & 389 & 4.04 & 1.46 & -0.014 & -0.504 & 4 & 28 \\
\hline MSPSS & 12 & 389 & 3.95 & 1.40 & 0.249 & -0.516 & 12 & 84 \\
\hline
\end{tabular}

Participants of the "sportsmanship status" T-Test results according to MSPSS points to variables are presented in Table 3. Table 3 levels of social support perceived by the students engaged in sports, as seen, showed a significant difference compared with those who do sports $\left[\mathrm{t}_{(542)}=8.566, \mathrm{p}<0.01\right]$. 
Table 3. T-Test results by an athlete status of variable rate MSPSS

\begin{tabular}{|l|l|l|l|l|l|l|l|}
\hline Scale & Sportsmanship Status & $\mathrm{n}$ & $\overline{\mathrm{x}}$ & $\mathrm{Ss}$ & $\mathrm{sd}$ & $\mathrm{t}$ & $\mathrm{p}$ \\
\hline \multirow{3}{*}{ MSPSS } & Yes & 155 & 5.07 & 1.33 & \multirow{2}{*}{$1-542$} & \multirow{2}{*}{8.566} & \multirow{2}{*}{$0.00^{* * *}$} \\
\cline { 2 - 9 } & No & 389 & 3.95 & 1.40 & & & \\
\hline
\end{tabular}

Note. $* * \mathrm{p}<0.01$.

Participants of the "sportmanship status" in terms of the dimensions of MSPSS is made variable according to the MANOVA for is showing significant differences. The mean and standard deviation value for the factors "sportsmanship status" by some of the factors that made one-way ANOVA results are shown in Table 4. According MANOVA results to determine whether significant differences in MSPSS the lower size, sportsmanship condition variable indicates a significant main effect on MSPSS factors $\left[\lambda=0.871, \mathrm{~F}_{(1.542)}=26651, \mathrm{p}<\right.$ 0.01]. This finding indicates that the points of SO, FAM and FIR obtained from the linear compound consisting of points vary depending on the hearing-impaired students. According to ANOVA results, in order to determine which dependent variable contributes to multivariate meaningfulness, SO points made that significant $\left[\mathrm{F}_{(1.542)}=78679, \mathrm{p}=0.00\right]$; FAM scores $\left[\mathrm{F}_{(1.331)}=51\right.$ 127, $\left.\mathrm{p}=0.00\right]$ and FRİ scores $\left[\mathrm{F}_{(1.331)}=47302, \mathrm{p}=0.00\right]$ engaged in sports and in favor of a significant difference in athletes than among the those who are not doing sports (Table 4).

Table 4. MSPSS athlete status by ANOVA results variable sub size

\begin{tabular}{|c|c|c|c|c|c|c|c|}
\hline Subscale & Sportsmanship Status & $\mathrm{n}$ & $\bar{x}$ & Ss & sd & $\mathrm{F}$ & $\mathrm{p}$ \\
\hline \multirow{2}{*}{ SO } & Yes & 155 & 4.93 & 1.55 & \multirow{2}{*}{$1-542$} & \multirow{2}{*}{78.679} & \multirow{2}{*}{$0.00 * *$} \\
\hline & No & 389 & 3.56 & 1.64 & & & \\
\hline \multirow{2}{*}{ FAM } & Yes & 155 & 5.30 & 1.45 & \multirow{2}{*}{$1-542$} & \multirow{2}{*}{51.127} & \multirow{2}{*}{$0.00 * *$} \\
\hline & No & 389 & 4.24 & 1.60 & & & \\
\hline \multirow{2}{*}{ FRİ } & Yes & 155 & 4.98 & 1.40 & \multirow{2}{*}{$1-542$} & \multirow{2}{*}{47.302} & \multirow{2}{*}{$0.00 * *$} \\
\hline & No & 389 & 4.04 & 1.46 & & & \\
\hline
\end{tabular}

Note. $* * \mathrm{p}<0.01$.

The T-Test results according to the MSPSS scores of the participants according to the "sport branch (team/individual)" variance are presented in Table 5. As can be seen in Table 5, the perceived social support of students who do team sports showed a significant difference compared to those who do individual sports in favor of those who do team sports $\left[t_{(153)}=\right.$ 
4.708, $\mathrm{p}<0.01]$.

Table 5. T-Test results of MSPSS scores according to sports branch variable

\begin{tabular}{|l|l|l|l|l|l|l|l|}
\hline Scale & Sports Branch & $\mathrm{n}$ & $\overline{\mathrm{x}}$ & $\mathrm{Ss}$ & $\mathrm{sd}$ & $\mathrm{t}$ & $\mathrm{p}$ \\
\hline \multirow{3}{*}{ MSPSS } & Team Sports & 112 & 5.36 & 1.31 & \multirow{2}{*}{153} & \multirow{2}{*}{4.708} & \multirow{2}{*}{$0.00^{*}$} \\
\cline { 2 - 9 } & Individual Sports & 43 & 4.31 & 1.08 & & & \\
\hline
\end{tabular}

Note. $* * \mathrm{p}<0.01$

A MANOVA was conducted to determine whether the sport branch (team/individual) variable showed a significant difference in terms of sub-dimensions of MSPSS. The mean and standard deviation values of the factors and the one-way ANOVA results based on the sports branch (team/individual) are shown in Table 6. MANOVA results show that the main effect of the sports branch variable on MSPSS factors is significant $\left[\lambda=0.853, \mathrm{~F}_{(1.153)}=8.673, \mathrm{p}<\right.$ 0.01]. According to the results of the ANOVA conducted to determine which dependent variable contributed to the multivariate significance, $S O$ scores $\left[\mathrm{F}_{(1.153)}=19.256, \mathrm{p}=0.00\right]$; FAM scores $\left[\mathrm{F}_{(1.153)}=25.014, \mathrm{p}=0.00\right]$ and FİR scores $\left[\mathrm{F}_{(1.153)}=10.574, \mathrm{p}<0.05\right] \mathrm{a}$ significant difference was found between the ones in favor of team sports compared to individual sports players. This finding showed that both MSPSS scores and the scores to be obtained from the linear components consisting of SO, FAM and FIR scores were higher in MSPSS and all three sub-components of those who do sports than those who do individual sports in team sports.

Table 6. ANOVA results of MSPSS sub-dimension scores by sports branch variable

\begin{tabular}{|c|c|c|c|c|c|c|c|}
\hline Subscale & Sports Branch & $\mathrm{N}$ & $\bar{x}$ & Ss & $\mathrm{sd}$ & $\mathrm{F}$ & $\mathrm{p}$ \\
\hline \multirow{2}{*}{ SO } & Team Sports & 112 & 5.25 & 1.58 & \multirow{2}{*}{$1-153$} & \multirow{2}{*}{19.256} & \multirow{2}{*}{$0.00 * *$} \\
\hline & Individual Sports & 43 & 4.09 & 1.12 & & & \\
\hline \multirow{2}{*}{ FAM } & Team Sports & 112 & 5.64 & 1.35 & \multirow{2}{*}{$1-153$} & \multirow{2}{*}{25.014} & \multirow{2}{*}{$0.00 * *$} \\
\hline & Individual Sports & 43 & 4.42 & 1.34 & & & \\
\hline \multirow{2}{*}{ FRİ } & Team Sports & 112 & 5.20 & 1.38 & \multirow{2}{*}{$1-153$} & \multirow{2}{*}{10.574} & \multirow{2}{*}{$0.01 *$} \\
\hline & Individual Sports & 43 & 4.41 & 1.29 & & & \\
\hline
\end{tabular}

Note. ${ }^{* *} \mathrm{p}<0.01,{ }^{*} \mathrm{p}<0.05$.

The T-Test results according to the MSPSS scores of the participants according to the "year 


\section{Ml Macrothink}

of doing sports" variance are presented in Table 7. As seen in Table 7, the perceived social support levels of students who do sports showed a significant difference compared to those who do not do sports $\left[\mathrm{t}_{(153)}=-4.152, \mathrm{p}<0.01\right]$. In other words, the MSPSS of students who do and do not do sports vary depending on the favor of those who do team sports.

Table 7. T-Test results of MSPSS scores according to the variable of years playing sports

\begin{tabular}{|l|l|l|l|l|l|l|l|}
\hline Scale & Year of Sport & $\mathrm{N}$ & $\overline{\mathrm{x}}$ & $\mathrm{Ss}$ & $\mathrm{Sd}$ & $\mathrm{T}$ & $\mathrm{p}$ \\
\hline \multirow{3}{*}{ MSPSS } & Between 1-5 years & 97 & 4.75 & 1.30 & \multirow{2}{*}{153} & \multirow{2}{*}{-4.152} & \multirow{2}{*}{$0.00^{*}$} \\
\cline { 2 - 6 } & Between 6-10 years & 58 & 5.60 & 1.21 & & & \\
\hline
\end{tabular}

Note. ${ }^{* *} \mathrm{p}<0.01$.

MANOVA was conducted to determine whether there was a significant difference in terms of sub-dimensions of Years of Sporting MSPSS. The mean and standard deviation values of the factors and the one-way ANOVA results based on the factor-based variable of the year of doing sports are shown in Table 8. MANOVA results show that the main effect of the variable of years of doing sports on MSPSS factors is significant $\left[\lambda=0.901, \mathrm{~F}_{(1.153)}=5.557, \mathrm{p}<0.01\right]$. This finding indicates that there is a significant difference between 1-5 years and 6-10 years in all three sub-components of the years of doing sports of the scores to be obtained from the linear components consisting of SO, FAM and FIR scores. According to the results of ANOVA conducted to determine which dependent variable contributed to the multivariate significance, $S O$ scores $\left[\mathrm{F}_{(1.153)}=15.050, \mathrm{p}=0.00\right]$; FAM scores $\left[\mathrm{F}_{(1.153)}=12.289 \mathrm{p}<0.05\right]$ and FIR scores $\left[\mathrm{F}_{(1.153)}=12.716 \mathrm{p}=0.00\right]$ are significant in favor of those who do sports between 1-5 years and 6-10 years. a difference was found (Table 8). When we look at the results of the hearing-impaired T-Test and MANOVA who do sports for 1-5 years and 6-10 years, the arithmetic averages of the students who do sports between 6-10 years are found to be higher. In other words, MSPSS and sub-dimensions of students who do and do not do sports vary depending on the favor of those who do sports for 6-10 years. 
Table 8. ANOVA results of MSPSS sub-dimensional scores according to years of exercise

\begin{tabular}{|c|c|c|c|c|c|c|c|}
\hline Subscale & Year of Sport & $\mathrm{N}$ & $\overline{\mathrm{x}}$ & Ss & $\mathrm{sd}$ & $\mathrm{F}$ & $\mathrm{p}$ \\
\hline \multirow{2}{*}{$\mathrm{SO}$} & Between 1-5 years & 97 & 4.57 & 1.56 & \multirow{2}{*}{$1-153$} & \multirow{2}{*}{15.050} & \multirow{2}{*}{$0.00 * *$} \\
\hline & Between 6-10 years & 58 & 5.23 & 1.36 & & & \\
\hline \multirow{2}{*}{ FAM } & Between 1-5 years & 97 & 4.99 & 1.47 & \multirow{2}{*}{$1-153$} & \multirow{2}{*}{12.289} & \multirow{2}{*}{$0.01 *$} \\
\hline & Between 6-10 years & 58 & 5.81 & 1.29 & & & \\
\hline \multirow{2}{*}{ FRİ } & Between 1-5 years & 97 & 4.68 & 1.37 & \multirow{2}{*}{$1-153$} & \multirow{2}{*}{12.716} & \multirow{2}{*}{$0.00 * *$} \\
\hline & Between 6-10 years & 58 & 5.48 & 1.32 & & & \\
\hline
\end{tabular}

Note. ${ }^{*} \mathrm{p}<0.01, * \mathrm{p}<0.05$.

\subsection{Related Results Satisfaction with Life Scale (SWLS)}

Table 9 Satisfaction with Life Scale (SWLS) scores from the arithmetic about the substance of mean, standard deviation, minimum and maximum values are given to the value of skewness and kurtosis. Among the participants who are the subject to the research, the arithmetic average and the standard deviation of the scores of the ones who do sports obtained from the SWLS of Table 9 was 4.91 \pm 1.30 ; the arithmetic average of the scores obtained from SWLS those who aren't engaged in sports and the standard deviation was $3.48 \pm 1.35$. Moreover, distortions regarding the participants in the SWLS had obtained a total score that satisfies the assumptions of normality and kurtosis are calculated. As seen in Table 9 , values related to these coefficients are calculated as distortion -..145, kurtosis -.744 for the athletes doing sports; and distortion .696, kurtosis -.210 for the ones not doing sports. The data is obtained from SWLS seen in the normal distribution assumption.

Table 9. Satisfaction with life scale score with relevant descriptive statistics

\begin{tabular}{|l|l|l|l|l|l|l|l|l|}
\hline Doing Sport & Article number & $\mathrm{n}$ & $\overline{\mathrm{x}}$ & Ss & Skewness & Kortosis & Min. & Mak. \\
\hline SWLS & 5 & 155 & 4.91 & 1.30 & -0.145 & -0.744 & 5 & 35 \\
\hline Not Doing Sport & Article number & $\mathrm{n}$ & $\overline{\mathrm{x}}$ & Ss & Skewness & Kortosis & Min. & Mak. \\
\hline SWLS & 5 & 544 & 3.48 & 1.35 & 0.696 & -0.210 & 5 & 35 \\
\hline
\end{tabular}

T-Test was carried out regarding the significant difference in SWLS factor. The T-Test results performed on the basis of factors according to the sportsmanship condition variance with mean and standard deviation values related to the elements are shown in Table 10. As seen in Table 10, life satisfaction of students who participate in sports, showed a significant difference when compared to those who doing not sports $\left[\mathrm{t}_{(542)}=-11349, \mathrm{p}<0.01\right]$. In other words, the SWLS scores of students who do and do not do sports have changed depending on 
doing sports. In the SWLS scores of athletes that no significant difference was detected, hearing impaired students who play sports have higher average scores in average points.

Table 10. T-Test results by an athlete status variables SWLS score

\begin{tabular}{|l|l|l|l|l|l|l|l|}
\hline Scale & Sportsmanship Status & $\mathrm{n}$ & $\overline{\mathrm{x}}$ & $\mathrm{Ss}$ & $\mathrm{sd}$ & $\mathrm{T}$ & $\mathrm{p}$ \\
\hline \multirow{3}{*}{ SWLS } & Yes & 155 & 4.91 & 1.30 & \multirow{2}{*}{542} & \multirow{2}{*}{11.349} & \multirow{2}{*}{$0.00^{* *}$} \\
\cline { 2 - 9 } & No & 389 & 3.48 & 1.35 & & & \\
\hline
\end{tabular}

Note. ${ }^{* *} \mathrm{p}<0.01$.

A T-Test was conducted to determine whether the sport branch (team/individual) variable showed a significant difference in terms of SWLS. The mean and standard deviation values of the factors and the T-Test results performed on the basis of the sport branch (team/individual) variable are shown in Table 11. As can be seen in Table 11, students' life satisfaction showed a significant difference between those who do team sports and those who do individual sports $\left[\mathrm{t}_{(153)}=-7.811, \mathrm{p}<0.01\right]$. In other words, the SWLS scores of students who do and do not do sports change in favor of team sports depending on the branch of sports (Table 11). When the T-Test results of the participants according to the sports branch variable were examined, a significant difference was found in favor of team sports in the SWLS and it was seen that the arithmetic averages of the hearing-impaired students who did team sports were higher than the arithmetic averages of the hearing-impaired students who did individual sports.

Table 11. T-Test results of SWLS scores according to sports branch variable

\begin{tabular}{|l|l|l|l|l|l|l|l|}
\hline Scale & Sports Branch & $\mathrm{n}$ & $\overline{\mathrm{x}}$ & $\mathrm{Ss}$ & $\mathrm{sd}$ & $\mathrm{t}$ & $\mathrm{p}$ \\
\hline \multirow{3}{*}{ SWLS } & Team Sports & 112 & 5.34 & 1.12 & \multirow{2}{*}{153} & \multirow{2}{*}{7.811} & \multirow{2}{*}{$0.00^{* *}$} \\
\cline { 2 - 8 } & Individual Sports & 43 & 3.80 & 1.04 & & & \\
\hline
\end{tabular}

Note. $* * \mathrm{p}<0.01$.

A T-Test was conducted to determine whether the variable of the year of doing sports showed a significant difference in terms of SWLS. The mean and standard deviation values of the factors and the T-Test results based on the factor based on the year of doing sports are shown in Table 12. The results of the analysis show that there is a significant difference in terms of the variable of years of doing sports among the students' SWLS scores $\left[\mathrm{t}_{(153)}=-7.304, \mathrm{p}<\right.$ 0.01] (Table 12). This difference shows that as the years of doing sports increase, their life satisfaction increases. When we look at the T-Test results of the years of doing sports of the 
hearing-impaired students who do sports for 1-5 years and 6-10 years, it was found that the arithmetic averages of the students who did sports between 6-10 years were higher. In other words, the SWLS of students who do and do not do sports vary depending on the favor of those who do sports for 6-10 years.

Table 12. T-Test results of the SWLS scores according to the variable of years of exercise

\begin{tabular}{|l|l|l|l|l|l|l|l|}
\hline Scale & Year of Sport & $\mathrm{n}$ & $\overline{\mathrm{x}}$ & $\mathrm{Ss}$ & $\mathrm{sd}$ & $\mathrm{t}$ & $\mathrm{p}$ \\
\hline \multirow{3}{*}{ SWLS } & Between 1-5 years & 97 & 4.41 & 1.16 & \multirow{2}{*}{153} & \multirow{2}{*}{-7.304} & \multirow{2}{*}{$0.00 * *$} \\
\cline { 2 - 9 } & Between 6-10 years & 58 & 5.77 & 1.06 & & & \\
\hline
\end{tabular}

Note. ${ }^{* *} \mathrm{p}<0.01$.

\subsection{Findings Related to the Relationship between Social Support and Life Satisfaction}

Pearson correlation test results Table 13 were presented in order to test the relationship between perceived social support and life satisfaction. In Table 13, analysis of the correlation between perceived social support and life satisfaction, a positive and significant realtion has been seen between perceived social support and moderate positive correlation and life satisfaction $[\mathrm{r}=0.62, \mathrm{p}=0.00]$.

Table 13. Correlation between social support and life satisfaction results

\begin{tabular}{|l|l|l|l|}
\hline \multirow{2}{*}{} & \multicolumn{3}{|c|}{ SWLS } \\
\cline { 2 - 4 } & $\mathrm{N}$ & $\mathrm{r}$ & $\mathrm{p}$ \\
\hline MSPSS & 544 & 0.62 & $0.00^{* *}$ \\
\hline
\end{tabular}

Note. $* * \mathrm{p}<0.01$.

\subsection{Related Results Predicting Life Satisfaction with Social Support}

Regression analysis results related to the prediction of life satisfaction according to sizes of perceived social support scale is shown in Table 14. As a result of regression analysis conducted as shown in Table 14, of sports in which students perceived social support, life satisfaction was found to be a significant predictor. There is a posistively and moderately significant relationship between social support perceived by students doing sports and their life satisfaction $(\mathrm{R}=0.472)$, which explains $22 \%$ of the total variance on life satisfaction perceptions. According to the results of the regression analysis, sports equation is shown below for the prediction of life satisfaction of doing sports:

$$
\text { Life Satisfaction }=2.58+0.5 \times \text { Perceived Social Support }
$$


Table 14. Between social support and life satisfaction regression results

\begin{tabular}{|l|l|l|l|l|l|}
\hline & $\mathrm{B}$ & Standard Error & $\beta$ & $\mathrm{t}$ & $\mathrm{P}$ \\
\hline Fixed & 2.58 & 0.37 & - & 7.07 & $0.00^{* *}$ \\
\hline Social Support & 0.46 & 0.07 & 0.47 & 6.62 & $0.00^{* *}$ \\
\hline
\end{tabular}

Note. ${ }^{* *} \mathrm{p}<0.01, \mathrm{R}=0.472, \mathrm{R}^{2}=0.223, \mathrm{~F}_{(1.153)}=43.828$.

\section{Discussion}

In this section, the findings obtained as a result of statistical analysis about the social support level and life satisfaction perceived by hearing impaired students studying in hearing impaired vocational high schools according to their sportsmanship status are evaluated and interpreted. The determined findings were supported by the findings obtained from the literature review on the subject.

Considering the elements that make up social support, it is emphasized that it is a process that is believed to emerge from spouses, friends and family members when needed (Başer, 2006). The mean and standard deviations of the perceived social support level scores of the hearing-impaired vocational high school students according to their athletic status are $5.07 \pm 1.33$ for those who do sports, and $3.95 \pm 1.40$ for those who do not do sports. The mean and standard deviations of the sub-dimensions of the scale of multidimensional perceived social support SO, FAM, and FIR were $4.93 \pm 1.55,5.30 \pm 1.45,4.98 \pm 1.40$, respectively, for those who do sports; those who do not do sports are $3.56 \pm 1.64,4.24 \pm 1.60,4.04 \pm 1.46$. This finding means the perceived social support of hearing-impaired students studying in deaf vocational high schools who do or do not do sports. Önalgil (2012), in his study examining the effect of physical activity on perceived social support, found that those who answered "yes" to physical activity had higher perceived social support and sub-dimension averages than those who answered "no". Similar to this study, this finding can also be expressed as that there is a significant relationship between family support, friend support, private person support, perceived social support with sport. In this study, when the sub-dimensions are examined, it is seen that the most perceived support score is obtained from FAM in those who do and do not do sports. Bursa (2010) determined that family support scores are higher than other subgroup scores of social support in the MSPSS score distribution of physically disabled individuals. Disabled people may tend to be alone due to the negative attitude of society towards them. In this case, it makes the disabled individual dependent on the family and increases family support. It can be thought that the high family support social score in the study is caused by that direction.

The mean and standard deviation values of the perceived social support level scores of the hearing impaired vocational high school students who do and do not play sports showed a significant difference in favor of those who do sports. In addition, when the sub-dimensions of the scale of multidimensional perceived social support were examined, a statistically significant difference was found in the mean and standard deviation values of SO, FAM and 


\section{Ml Macrothink}

FIR scores according to athletic status. In other words, the perceived social support levels of the participants changed depending on their athletic status. Önalgil (2012) found a significant difference between family support, friend support, private person support, and general perceived social and physical activity in his study on the effect of physical activity on perceived social support and well-being in individuals aged 55 and over. Berkman's (1979) study also supports the research findings. The sharing of knowledge and experience in the exercise groups was perceived as the instrumental social support type; and calling their friends to watch the program, accompanying their friends and/or encouraging their friends to participate were given as the emotional social support type. It has been emphasized that these types of social support also indirectly affect the exercise habit (doing the exercise in regular daily or weekly periods). In the study of DiPietro (2001), it was determined that there was a significant relationship between social support from friends and siblings (family) and physical activity levels. Smoll, Smith, Barnett, and Everett (1993) investigated whether sports coaches' self-esteem levels increased after social support training. Social support training was given to the coaches in the experimental group, and no implementation was made to the coaches in the control group. As a result of the research, it was revealed that the behaviors of the coaches who received training differed from those who did not. Sports provide the physical, mental and social development of the disabled and facilitate their integration into the society (Eichsteadt \& Lavay, 1995). For this reason, sports should be considered as a tool in order to ensure the adaptation of people with disabilities to society, accelerate this process and contribute to their socialization (Dunn \& Fait, 1997). Therefore, it can be concluded that individuals who perceive themselves as an active person have a higher perception of social support.

There was a statiscally significant difference between the mean and standard deviation values of the perceived social support level scores of the students studying at the hearing-impaired vocational high schools doing sports and the sport branch (team/individual) variable. When the sub-dimensions of the scale of multidimensional perceived social support are examined, the mean and standard deviation values of SO, FAM and FİR scores differed significantly according to the variable of being involved in individual or team sports. In other words, the perceived social support levels of the participants depending on their interest in individual or team sports differed in favor of those who do team sports. When the literature was reviewed no studies on the concept of social support examining the sport branch (team/individual) variable have been found. The fact that the findings were significant in favor of those who do team sports may be due to the fact that they perceive the support of their friends more. In addition, a possible reason to that result may be that the sports branches such as football, basketball and volleyball are in the forefront in our country and there is a greater interest in these sports branches. On the other hand, the lack of interest in individual sports in our country and the lack of awareness of different individual sports branches can be thought among other reasons.

A significant difference was found when the mean and standard deviation values of the perceived social support level scores of the students studying at the hearing-impaired vocational high schools doing sports compared with the variable of years of doing sports. 


\section{MInstitute Macrink $_{\text {ins }}$}

When the sub-dimensions of the scale of multidimensional perceived social support are examined, the mean and standard deviation values of the SO, FAM and FIR scores differ statistically significantly according to the year of doing sports. In other words, the perceived social support levels of the participants changed in favor of those who did sports for a longer period of time, depending on the year of doing sports. When the literature is examined, no studies on social support examining the variable of years of doing sports have been found. Since sports are thought to have many features such as socializing and integrating, it is thought that people who are interested in sports for a longer time are more social and their perceived social support level is higher.

The mean and standard deviations of the life satisfaction level scores of the students who do or do not do sports at vocational high schools for the hearing impaired are $4.91 \pm 1.30$ for those who do sports and $3.48 \pm 1.35$ for those who do not do sports. It is seen that the life satisfaction scores of the participants are above the average in favor of those who do sports. Gezer (2014) investigated the life satisfaction average of members of the police force who do and do not do sports and found that it was higher in men who do sports. This finding is similar to our study and shows that there is a significant relationship between sports and life satisfaction on individuals. It can be said that the significant result is due to the happiness hormone (serotonin/endorphin) secreted by sports to individuals.

The mean and standard deviation values of the life satisfaction level scores of hearing-impaired students studying at vocational high schools with or without sports were statistically significant in favor of those who do sports. Sport nourishes the sense of achievement, self-confidence, attachment to life and enjoying life in the lives of disabled individuals as well as in healthy individuals (Duman, Baştuğ, Taşğın, \& Akandere, 2011). Kapıkıran and Yağcı (2010) found that doing sports in adolescents is directly related to life satisfaction. Ayça (2013) revealed in her study that the exercise group had an increase in life satisfaction after 3 months of exercise. In the 1st international congress of physical education and sports for the disabled, it was argued that disabled individuals who do sports have a higher perception than those who do not, and their life satisfaction is found to be higher (Çalışkan, 2011). Doğan and Moralı (1999), in their study examining the attitudes of university lecturers towards sports and their life and job satisfaction levels, found that the life satisfaction values of the lecturers who do sports are higher than those of the lecturers who do not do sports. In his study investigating goal orientation, motivational (motivational) climate and life satisfaction in elite and non-elite male basketball players, Toros (2002) applied a life satisfaction scale to 148 elite basketball players in the 1st league and 88 non-elite basketball players in the 2 nd league at the beginning of the league. It has been determined that the life satisfaction of the athletes is higher than the non-elite athletes.

In the last measurement applied at the end of the league, it was determined that the life satisfaction of the elite athletes was higher than the non-elite athletes. Contrary to the research findings, Kumartaşlı (2010) did not find a significant difference between life satisfaction and the variable of exercising or doing sports in his study. There was no significant relationship between the life satisfaction levels of the students participating in the study and the variables of going to the preparatory course and doing sports. However, it was 
determined that there was a significant relationship between the attitude of the students participating in the study towards the physical education lesson and their life satisfaction. It has been determined that the attitude towards physical education lesson affects life satisfaction. In the study of Duman et al. (2011) examining the relationship between self-confidence and life satisfaction in physically disabled athletes, no significant difference was found in the life satisfaction values of physically disabled children who do sports. He attributed this to the fact that the physically disabled child received life satisfaction in parallel with his/her self-confidence. Depending on the results obtained from the research, it can be said that the significant life satisfaction of the disabled individuals who do sports is an indicator of the positive effects of sports on the happiness hormone secreted in the human body and the life satisfaction of the individuals who do sports as a result of the effect of this hormone, in other words, on the well-being.

When the mean and standard deviation values of the life satisfaction level scores of the students studying at the hearing-impaired vocational high schools doing sports compared to the sports branch (team/individual) variable, a statistically significant difference was found. In other words, the perceived social support levels of the participants depending on their interest in individual or team sports differed in favor of those who do team sports. When the literature was reviewed no studies found on the concept of social support examining the effect of the sport branch (team/individual) variable. The fact that the results are in favor of those who do team sports may be due to the fact that individuals who do team sports interact more with each other, share success or failure better, and thus support each other more.

A statistically significant difference was found between the mean and standard deviation values of the life satisfaction level scores of the students studying at the hearing-impaired vocational high schools playing sports and the variable of years of doing sports. In the study of Pense, Demir, and Lesinger (2011) when the relationship between the self-perceptions of disabled individuals and their sports experiences was examined, it was determined that there were differences between those who had more than 5 years of sports experience and those who had less than 5 years of sports experience. It has been observed that disabled athletes who have more than 5 years of sports experience have higher self-perception scores. It can be concluded that the person who is interested in sports for a longer period of time can feel more fit biologically, physiologically and psychologically, and thus naturally reaches life satisfaction, which is the sub-component of well-being.

As a result of the correlation test performed to determine the relationship between social support and life satisfaction, a moderately positive relationship was found between social support and life satisfaction. Önalgil (2012) found a moderate, positive and significant relationship between well-being and perceived social support in his study on the effect of physical activity on perceived social support and well-being in individuals aged 55 and over. He found a low level, positive and significant relationship between well-being and personal support. A moderate, positive and significant relationship was found between well-being and friend support and family support. Looking at the subscales, it is seen that family support is more effective than other supports. Fife, Adegoke, Mccoy, and Brewer (2011) found a positive relationship between social support and life satisfaction in their study named 
religious commitment, life satisfaction, and social support among college students. Wan and Jaccard (1996) also found a positive relationship between social support and life satisfaction (Wan \& Jaccard, 1996; Cited Yetim, 2001). When we look at the study of Masako (1987) with different age groups, they found that there is a significant relationship between well-being and social support. It was concluded that family support was at a high level, and then the support of friends came. In addition, in the study, it was determined that there is a significant relationship between the availability of the family in old age and the state of well-being. Guerrette (2011) found a significant relationship between perceived social support and well-being. Kafetsios (2006) found a significant difference between social support and well-being in the study of young and old groups. In many studies, a positive relationship was found between satisfaction from friendships and subjective well-being (Anderson, 1977; Campbell, Converse, \& Rodgers, 1976; Falkman, 1973; Cited Yetim, 2001). In this study, it can be thought that as the perceived social support levels of disabled individuals increase, their perspectives towards life may be positive and thus their life satisfaction will be positive. In this case, the support from family, friends and environment may be perceived more positively. We mentioned in perceived social support; The importance of social support being in line with the person's own perception, what needs the person meets, and how the person perceives the situation, events and results can determine the relationship with life satisfaction. If the person is happy and approaching life positively, the support given to the person may reach the person and the person may perceive this support. Besides, as the person is supported socially, keeping the communication lines open with their social networks, the likelihood of them being alone is lowered.

It has been determined that perceived social support is a significant predictor of life satisfaction of hearing-impaired students who do sports. According to this finding, perceived social support of hearing-impaired students who do sports explains $22 \%$ of the total variance on their life levels. According to Welk's (1999) Youth Model of Physical Activity Development, the factors affecting participation in physical activity: predisposition, social support, facilitators and demographic characteristics (age, gender) are also interrelated. Therefore, it can be inferred that life satisfaction is affected by factors such as family, friends, and special human support.

In this of the research, the results on analyzing the perceived social support and life levels of hearing-impaired students who both do sports and not are included. In the light of questions about personal information of perceived social support and life levels of hearing disabled students who do sports or not, this study, which aims to state the perceived social support and life levels of these students, can be summed up in this way. According to this data perceived social support and life levels of hearing disabled students is at a higher level than average among the ones doing sports. The perceived social support levels and life satisfaction of the hearing-impaired students who do sports were found to be significant in favor of those who are interested in team sports. The perceived social support levels and life satisfaction of hearing-impaired students who do sports differ significantly in favor of those who do sports for a longer period of time. The perceived social support and life levels of hearing disabled students have been found meaningful with a positive relation in the ones doing sports. A 
positive average level relation between perceived social support and life satisfaction is found. The perceived social support and life satisfaction of hearing-impaired students who do sports are stated with a rate of $22 \%$. Social support perceived by hearing impaired students who do sports is an important predictor of their life satisfaction.

In the light of these results; It should be ensured that an educational environment is created that will enable the hearing impaired to get to know themselves and develop their personalities, and physical education and sports activities that increase the level of life satisfaction and increase perceived social support should be provided in order to raise successful and mentally healthy individuals. It is seen that sports affect the perceived social support and life satisfaction of hearing-impaired students positively. For this reason, it is necessary to work on their participation in sports activities and sports competitions. Based on the conclusion that being involved in sports for a long time increases their perceived social support and life satisfaction, it should be ensured that a life-long understanding of sports is adopted by starting children to sports at a young age. Considering that individuals interested in team sports increase their perceived social support and life satisfaction, individuals should be directed to team sports. The benefits of sports can be instilled in children by explaining the essence of sports activities in a good way, by suggesting that losing is as common as winning in sports and that success should be shared. Rehabilitation of persons with disabilities is a general problem not only for their families, but also for society. Within the framework of this awareness, encouraging activities can be carried out to increase participation in sports activities, which are seen to be effective in the rehabilitation of the disabled.

\section{References}

Akkan, E. (2010). The predictive power of emotional intelligence and creativity levels of gifted students in secondary education on their life satisfaction (Unpublished Master's thesis, Gaziosmanpaşa University, Tokat).

Armsden, G. C., \& Greenberg, M. T. (1987). The inventory of parent and attachment individual difierences and their relationship to psychological well-being in adolescence. Journal of Youth and Adolescence, 16(5), 427-454. https://doi.org/10.1007/BF02202939

Ayça, M. (2013). The effect of goalball sport on the physical performance of visually impaired children and their and their families' life satisfaction and hopelessness levels (Unpublished Master's thesis, Ondokuz Mayıs University, Samsun).

Barrera, M., Chassin, L., \& Logosch, F. (1993), Effects of social support and conflict on adolescent children of alcoholic and nonalcoholic fathers. Journal of Personality and Social Psychology, 64(4), 215-229. https://doi.org/10.1037/0022-3514.64.4.602

Başbakanlık Özürlüler İdaresi Başkanlığı. (2009). Disability education: Basic research on how society understands disability. Ankara: Yazar.

Başer, Z. (2006). Investigation of the relationship between perceived social support from the family and the level of self-acceptance (Unpublished Master's thesis, Atatürk University, Erzurum). 


\section{Ml Macrothink}

Journal of Educational Issues ISSN 2377-2263

Berkman, L. F. (1979). Social networks, host resistance and mortality; A nine year follow-up study of alameda county residents. American journal of Epidemiology, 109(2), 186-204. https://doi.org/10.1093/oxfordjournals.aje.a112674

Brouwer, J., \& Ludeke, W. (1995, Ekim). Sport for the disabled from a philosophical point of view. Antalya Uluslararası Engellilerde Spor Sempozyumu, T.C. Başbakanlık Gençlik ve Spor Genel Müdürlüğü Spor Eğitimi Dairesi Başkanlığı, Ankara.

Bursa, D. (2010). Depression and multidimensional perceived social support level in individuals with physical disabilities (Unpublished Master's thesis, Selçuk University, Konya).

Büyüköztürk, Ş. (2013). Manual of data analysis for social sciences. Ankara: Pegem Akademi.

Çakır, H. Y. (1993). Reliability and validity research of multidimensional perceived social support scale in young people aged 12-22 (Unpublished Master's thesis, Ankara University, Ankara).

Çakır, Y., \& Palabıyıkoğlu, R. (1997). Reliability and validity study of the multidimensional perceived social support scale of youth social support. Kriz Journal, 12(5), 15-24.

Çalışkan, E. (2011). Sports education in disabled children and the approaches of families. In N. Erkmen, S. Revan, E. Çakmakçı \& A. Bozdam (Eds.), 1 Uluslararası Katılımlı Engellilerde Beden Ĕgitim ve Spor Kongresi içinde (pp. 30-33). Konya: Selçuk University.

Canetti, L., Bachar, E., Galili-Weisstub E., De-Nour A. K., \& Shalev, A. Y. (1997). Parental bonding and mental health in adolescence. Adolescence, 32(126), 381-394.

Çeçen, A. R. (2008). Examining the loneliness and social support levels of students according to their gender and parental attitude perceptions, Türk Eğitim Bilimleri Journal, 6(3), 415-431.

Çeçen, A., R. (2007). Examining the social and emotional loneliness levels of university students according to their gender and life satisfaction levels. Mersin University Ĕgitim Fakültesi Journal, 3(2), 180-190.

Cheng, C. (1997). Role of perceived social support on depression in chinese adolescents. A prospective study examining the buffering model. Journal of Applied Social Psychology, 27(9), 800-820. https://doi.org/10.1111/j.1559-1816.1997.tb00660.x

Chow, H. P. H. (2005). Life satisfaction among university students in a canadian prairie city: A multivariate analysis. Social Indicators Research, 70(2), 139-150. https://doi.org/10.1007/ s11205-004-7526-0

Çöndü, A. (2004). Special teaching methods in physical education and sport (2nd ed.). Ankara: Nobel Yayın Dağıtım.

Demaray, M. K., \& Malecki. C. K. (2002). The relationship between perceived social support and maladjustment for students at risk. Psychology in the Schools, 39(3), 305-316. 
https://doi.org/10.1002/pits.10018

Deniz, M. E., \& Y1lmaz, E. (2004). The relationship between university students' emotional intelligence abilities and life satisfaction. XIII Ulusal Eğitim Bilimleri Kurultayı, İnönü University, Malatya.

Diener, E., \& Fujita, F. (1995). Resources, personal striving and subjective well-being. Journal of Personality and Social Psychology, 69(1), 120-132. https://doi.org/10.1037/ 0022-3514.69.1.120

Diener, E., \& Seligman, P. (2004). Beyond money: Toward an economy of well-being. Psychological Science in the Public Interest, 5, 1-31. https://doi.org/10.1111/j.0963-7214. 2004.00501001.x

Diener, E., Emmons, R. A., Larsen, R. J., \& Griffin, S. (1985). The Satisfaction with Life scale. Journal of Personality Assessment, 49(1), 71-75. https://doi.org/10.1207/s15327752 jpa4901_13

Dikmen, A. A. (1995). The relationship between job satisfaction and life satisfaction in public employees (Unpublished Master's thesis, Ankara University, Ankara).

Dillman, P., \& Salant, D. A. (1994). How to conduct your own survey. New York: Wiley.

DiPietro, L. (2001). Physical activity in aging changes in patterns and their relationship to health and function. Journals of Gerontology: Series A, 56A, 13-22. https://doi.org/10.1093/ gerona/56.suppl_2.13

Doğan, B., \& Moral1, S. (1999). Examining the attitudes of university lecturers about sports and their level of life and job satisfaction with their sports habits. Beden Eğitimi ve Spor Bilimleri Journal, 3(1), 16-17.

Doğru, Ö. (2004). Children with special needs and their education. Bilim ve Aklın Aydınlığında Eğitim Journal, 5(56), 35-47.

Ducharme, J., Doyle, A. B., \& Markiewicz, D. (2002), Attachment security with mother and father: associations with adolescent reports of interpersonal behavior with parents and peers. Journal of Social and Personal Relationship, 19(2), 203. https://doi.org/10.1177/0265407502 192003

Duman, S., Baştuğ, G., Taşğın, Ö., \& Akandere, M. (2011). Investigation of the relationship between self-confidence and life satisfaction level in physically disabled athletes. Uluslararasi Insan Bilimleri Journal, 8(1), 1364-1373.

Dunn, J. M., \& Fait, H. (1997). Special physical education: Adapted, individualized, developmental (7th ed.). Madison: Brown and Benchmark Publishers.

Eichsteadt, C. B., \& Lavay, B. W. (1995). Physical Activity for Individuals with Mental Retardation Compaign (p. 47). Illinois, USA.

Eker, D., \& Arkar, H. (1995). Factor structure, validity and reliability of the multidimensional 
scale of perceived social support. Türk Psikoloji Journal, 10(34), 45-55.

Eker, D., Arkar, H., \& Yaldız, H. (2001). Factor structure, validity and reliability of the revised form of the multidimensional scale of perceived social support. Türk Psikiyatri Journal, 12(1), 17-25.

Erelçin, F. G. (1988). Coltectivistic norms in Turkey: Tendency to give and receive support (Unpublished Master's thesis, Boğaziçi University, İstanbul).

Etci, A. (2013). The relationship between learned resourcefulness and hopelessness levels of hearing impaired students (Unpublished Master's thesis, Yeditepe University, İstanbul).

Fife, J., Adegoke, A., Mccoy, J., \& Brewer, T. (2011). Religious commitment, social support and life satisfaction among college students. College Student Journal, 45(2), 393-400.

Gençdoğan, B. (2003). Relationships between high school students' test anxiety and submissiveness levels and perception of social support. In H. Atılgan \& M. Saçkes (Eds.), VII Ulusal Psikolojik Danışma ve Rehberlik Kongresi Bildiri Özetleri Içinde (p. 148). Ankara: Türk Psikolojik Danışma ve Rehberlik Derneği.

Gezer, H. (2014). Investigation of life satisfaction and burnout levels of law enforcement personnel who do and do not do sports (Malatya example) (Unpublished Master's thesis. Muğla Sitkı Kocaman University, Muğla).

Gilman, R. (2001). The Relationship between life satisfaction, social interest, and frequency of extracurricular activities among adolescent studies. Journal of Youth and Adolescence, 30(6), 749-767. https://doi.org/10.1023/A:1012285729701

Goldbeck, L., Schmitz, T. G., Besier, T., Herschbach, P., \& Henrich, G. (2007). Life satisfaction decreases during adolescence. Qual Life Res Abstract, 16(6), 969-79. https://doi.org/10.1007/s11136-007-9205-5

Guerette, A. S., \& Smedema, S. (2011). The relationship of perceived socail support with well-being in adults with visual impairments. Journal of Visual Impairment and Blindness, 105(7), 425-439. https://doi.org/10.1177/0145482X1110500705

Gürbüz, A. G. (2008). Investigation of the effects of anger management training on senior high school students' ability to cope with anger, their life satisfaction and depression levels (Unpublished Master's thesis, Dokuz Eylül University, İzmir).

Hilooğlu, S. (2009). The role of social skills and life satisfaction in predicting bullying behaviors of secondary school students (Unpublished Master's thesis, Çukurova University, Adana).

Kafetsios, K. S. (2006). Attacahment, social support and well-being in young and older adults. Journal of Health Psychology, 11(6), 863-75. https://doi.org/10.1177/1359105306069084

Kapıkıran, Ş., \& Yağc1, U. (2010). Investigation of mediating and mediating role of some variables on life satisfaction of adolescents. XIX Ulusal Eğitim Bilimleri Kongresi, Uluslararası Kibris University, Kibrıs. 
Karasar, N. (2012). Scientific research method. Ankara: Nobel Akademik Yayınc1lık.

Kargın, T. (2004). Inclusion: Definition, development and principles. Ankara University Ĕ̈itim Bilimleri Fakültesi Özel Eğitim Journal, 5(2), 1-13.

Kay, B. (2002). Perceived social support levels of mothers and fathers with mentally retarded and non-disabled children (Unpublished Master's thesis, Ankara University, Ankara).

Kaya, Ö. (2006). A research on life satisfaction of military students. (Unpublished Master's thesis, Gazi University Eğitim Bilimleri Enstitüsü. Ankara).

Kılıç, E. Ö., Özbay, H., Gökay, E., Aktaş, A. M., \& Güngör, S. (1994). Adolescents' social support environments: A comparative study between workers and students. Türk Psikiyatri Journal, 5(2), 119-125.

Kıncal, R. (2004). Introduction to the teaching profession. Ankara: Nobel Yayın Dağıtım.

Kırc1-Çevik, N., \& Korkmaz, O. (2014). Bivariate sequential probit model analysis of the relationship between life satisfaction and job satisfaction in Turkey. Niğde University IIIBF Journal, 7(1), 126-145.

Kırkbir, F., \& Zengin, S. (2020). The relation between burnout in sport and life satisfaction: A research on university students. International Journal of Applied Exercise Physiology, 9(10), 73-78.

Kjøbli, J., \& Ogden, T. (2009). Gender differences in intake characteristics and behavior change among children in families receiving parent management training. Children and Youth Services Review, 31(8), 823-830. https://doi.org/10.1016/j.childyouth.2009.03.004

Kline, R. B. (2011). Principles and practice of structural equation modeling. A Division of Guilford Publications.

Köker, S. (1991). Comparison of life satisfaction levels in normal and problem adolescents (Unpublished Master's thesis, Ankara University, Ankara).

Korkut, Ş. (2012). Investigation of the relationships between childhood trauma experiences and anger expression styles, self-esteem and life satisfaction in high school students (Unpublished Master's thesis, Çukurova University, Adana).

Kumartaşl1, M. (2010). Examination of primary school secondary school students' attitudes towards physical education lesson and their level of life satisfaction (Unpublished Doctoral thesis, Gazi University, Ankara).

Kuzu, A. (2013). Scientific research methods. Eskişehir: Anadolu University Yayını.

Lan-Liu, Y. (2006). Paternal/Maternal attachment, peer support social expectations of peer interaction and depressive symptoms. Adolescence, 41(164), 705-721.

Leavy, R. L. (1983). Social support and psychological disorder: A review. Journal of Community Psychology, 11(1), 3-21. https://doi.org/10.1002/1520-6629(198301)11:1\%3C3:: AID-JCOP2290110102\%3E3.0.CO;2-E 
Masako, I. K. (1987). The impact of informal social support on well-being; comparison cross stages of adulthood (pp. 1-24). 49th Annual Conference of the National Council of Family Relations, Atlanta.

Mason, W. A. (2004). General and specific predictors of behavioral and emotional problems among adolescents. Journal of Emotional and Behavioral Disorders, 12(1), 49-61. https://doi.org/10.1177/10634266040120010601

Myers, D. G., \& Diener, E. D. (1995). Who is Happy? Psychological Science, 6(1), 10-17. https://doi.org/10.1111/j.1467-9280.1995.tb00298.x

Nicpon, M. (2007). The relationship of loneliness and social support with college freshmen's acaemic performance and persistence. Journal of College Student Retention, 8(3), 45-358. https://doi.org/10.2190/A465-356M-7652-783R

Okanl1, A. (1999). The relationship between the social support perceived by nursing students from their family and friends and their anxiety level (Unpublished Master's thesis, Atatürk University, Erzurum).

Önalgil, S. (2012). The effect of physical activity on perceived social support and well-being in individuals aged 55 and over (Yayınlanmış Yüksek Lisans tezi, Akdeniz University, Antalya).

Özdinç, Ö. (2005). Opinions of Çukurova University students on the relationship between sports and participation in sports and socialization. Spormetre Journal, 3(2), 77-78.

Özer, S. D. (2010). Physical education and sport for the disabled. Ankara: Nobel Yayın Dağıtım.

Pense, M., Demir, H., \& Yaman-Lesinger, F. (2011). Investigation of self-perception in disabled athletes according to various variables. Selçuk Unıversity Journal of Physical Education And Sport Science, 13, 48-53.

Perrone, K. M., Webb, L. K., \& Jackson, V. Z. (2007). Relationships between parental attachment, work and family roles and life satisfaction. The Career Development Quarterly, 55(3), 237-246. https://doi.org/10.1002/j.2161-0045.2007.tb00080.x

Rigby, K. (2000). Effects of peer victimization in schools and perceived social support on adolescent well-being. Journal of Adolescence, 23(1), 57-68. https://doi.org/10.1006/jado. 1999.0289

Rueger, S. (2010). Relationship between multiple sources of perceived social support and psychological and academic adjustment in early adolosence. Journal of Youth and Adolesence, 39(1), 47-61. https://doi.org/10.1007/s10964-008-9368-6

Savi-Çakar, F., \& Karataş, Z. (2012). Adolescents' self-esteem, perceived social support and hopelessness levels: A structural equation model study. Kuram ve Uygulamada Ĕ̆itim Bilimleri, 12(4), 2397-2412.

Şencan, B. (2009). Examination of high school students' perceived social support level and 
social competence expectation levels according to some variables (Unpublished master's thesis, Çukurova University, Adana).

Sevindi, T. (2002). Investigation of reaction times of 11-14 age group male students with and without hearing impairment (Unpublished master's thesis, Niğde University, Niğde).

Siklos, S., \& Kerrns, K. (2006). Assessing need for social support in parents of children with autism and down syndrome, Journal of Autism Development Disorders, 36(7), 921-33. https://doi.org/10.1007/s10803-006-0129-7

Şimşek, A. (2012). Research methods in the social sciences (1st ed.). Eskişehir: Anadolu University Açıköğretim Fakültesi Publications.

Şirvanl1-Özen, D. (1998). The role of spousal conflict and divorce on behavior and adjustment problems and perceived social support of children of different ages and genders (Unpublished Doctoral thesis, Hacettepe University, Ankara).

Smoll, F. L., Smith, R. E., Barnett, N. P., \& Everett, J. J. (1993). Enhancement of children's self-esteem through social support training for youth sport coaches. Journal of Applied Psychology, 78(4), 602-610. https://doi.org/10.1037/0021-9010.78.4.602

Sorias, O. (1988a). Social support concept. Tıp Fakültesi Journal, 27(1), 353-357.

Sorias, O. (1988b). Investigation of the protective effect of social supports on mental health in depressed and healthy controls. Tip Fakültesi Journal, 27(3), 1033-1039.

Soylu, Ö. (2002). Examination of students preparing for the university exam in terms of psychological symptoms according to their perception of social support from their families (Unpublished Master's thesis, Çukurova University, Adana).

Taş, İ. (2011). Examination of teachers' meaning of life, life satisfaction, social comparison and internal-external locus of control in terms of various variables (Unpublished Master's thesis, Sakarya University, Sakarya).

Toros, T. (2002). Goal orientation, motivational climate and life satisfaction in elite and non-elite male basketball players. İstanbul Spor Bilim Journal, 13 (3), 24-36.

Ünal, A. Ö., \& Şahin, M. (2013). Predicting life satisfaction of high school students according to some variables. Cumhuriyet International Journal of Education, 2(3), 46-63.

Ünlü, H. (2001). Investigation of perceived social support and ego identity status of high school students according to socio-economic level and gender (Unpublished Master's thesis, Gazi University, Ankara).

Ustabaş, S. (2011). Examination of primary school 8th grade students' aggression and perceived social support levels according to some variables (Unpublished Master's thesis, Gazi University, Ankara).

Varış, F. (1991). Introduction to educational sciences. Ankara: A. Ü. Faculty of Education Publication. 


\section{Macrothink}

Vinson, T., \& Ericson, M. (2012). Life satisfaction and happiness. Richmond: Jesuit Social Services.

Welk, G. J. (1999). The youth physical activity promotion model: A conceptual bridge between theory and practice. Quest, 51, 5-23. https://doi.org/10.1080/00336297.1999. 10484297

Yalçın, İ. (2004). Aggression levels of high school students with different levels of perceived support from their families (Unpublished Master's thesis, Hacettepe University, Ankara).

Yalçın, İ. (2015). Relationships between well-being and social support: A meta-analysis of studies conducted in Turkey. Türk Psikiyatri Journal, 26(1), 21-32.

Yarcheski, A., Mahon, M. N., \& Thomas, J. Y. (2001). Social support and well-being in early adolescents: the role of mediating variables, Clinical Nursing Research, 10(2), 163-181. https://doi.org/10.1177/10547730122158851

Yetim, Ü. (2001). Pictures of happiness from society to individual. İstanbul: Bağlam Publications.

Yıldırım, A., \& Şimşek, H. (2005). Qualitative research methods in the social sciences (5th ed.). Ankara: Seçkin Yayıncılık.

Y1ldırım, İ. (2000). Loneliness, test anxiety and social support as predictors of academic success. Hacettepe University Ĕ̈itim Fakültesi Journal, 18, 167-176.

Young, M. H., \& Miller, B. C. (1995). The effect of parental supportive behaviors on life satisfaction of adolescent offspring. Journal of Marriage and Family, 57(3), 813-822. https://doi.org/10.2307/353934

Zaimoğlu, S. (1991). Perception of social support in adolescents (Master thesis, Akdeniz University, Antalya).

Zimet, G. D., Dahlem, N. W., Zimet, S. G., \& Farley, G. K. (1988). The multidimensional scale of perceived social support. Journal of Personality Assessment, 52(1), 30-4. https://doi.org/10.1207/s15327752jpa5201_2

\section{Copyright Disclaimer}

Copyright for this article is retained by the author(s), with first publication rights granted to the journal.

This is an open-access article distributed under the terms and conditions of the Creative Commons Attribution license (http://creativecommons.org/licenses/by/3.0/). 